\title{
Impact of Casteism in Dalit Women: A Contextual Study of Jyoti Lanewar's
}

\section{"Mother"}

Benlin Anand S S

MA, NET

Chennai, Tamil Nadu, India

benlinanand@gmail.com

\begin{abstract}
The intention of this article is to bring out the effect of casteism over dalit women who are suppressed as a dalit and also as women. This article shows light on the oppression imposed over the dalits in daily basis, which is prevailing even today in every possible forms. This article also deals with how "Mother", as a woman was also gets affected by the patriarchy, which includes men of so called upper castes and lower caste and also how she was abused by her husband. The self-respect of the dalits and also the unnoticed hard work of them for the development of the country from healthcare to infrastructure is also discussed in this article. Education is the only way which helps dalits to rise their voice out of the oppression over them. This poem "Mother" deals with every aspect of dalit life and their constant struggle to come out of it.
\end{abstract}

Keywords: Dalits, Caste, Education, Women.

Mother is a poem explaining the plight of a Dalit woman. It is a daughter's point of view about her "Mother's"life as a Dalit woman. She faced problems both as a woman and a member of lower caste. It also talks about her concern about the society though she was working hard to earn her daily food. She fought against several social injustice. The poem also talks about how people of lower caste were exploited of their work and were seldom 
given the recognition for their work. Caste is a predominant theme of this poem as it speaks about the struggles of a Mother from a lower caste.

Jyoti Lanjewar was born in Nagpur, Maharashtra, on $25^{\text {th }}$ November 1950 . Her family has dedicated themselves to fight against social injustice and to speak on social issues. She did her masters, M.Phil and Ph.D at Nagpur and became a permanent professor and head of Marathi at SB city college, Nagpur. She was a Marathi writer, critic, poet, feminist scholar and social activist. She wrote 4 poetry collection, 7 books on criticism and some other works. Her poems have been translated to several Indian and foreign languages and were taught in several universities over India and abroad. Her books speaks about variety of themes such as womanhood, motherhood, friendship, honest, commitment, human values and love. Her writings destroys those stereotypes and conventions prevailing in the society based on gender, caste, class etc. She is a recipient of numerous awards.

In this poem Mother, Jyoti Lanjewar speaks about the selflessness and sacrifice of the mother. This poem can also be interpreted in the view of Dalit feminism as it deals with the plights of Dalit women and how they were treated in the society. The Mother in this poem works on the road construction. Her children were hanging in a cradle in a tree. She works under the scorching sun without any sandals for her sole.

People of particular caste were suppressed for centuries. Education were denied to them. They were treated as slaves by the people of higher caste for several hundred years. Over years the people of so called lower caste started to consider themselves as slaves. This helps the higher caste people to exploit their work, wealth etc. Several reformers fought against such social injustice and brought some rights for the people.Gail Omvedt in his book Dalit Visions explains the rise of Dalit movements in 1980s as, "The 1980s were marked not only by the assertion of Dalits and other lower castes, but also by the rise of other new social 
movements, of peasants fighting against their exploitation by the market and state of women, of tribal and caste Hindu..." (82).

In this poem, as Lanje war says, Mother was working on the road construction. "Carrying barrels of tar/ working on a road construction crew" (Mother 99). Roads are the main face of a city's infrastructure development. Roads in metropolitan cities were constructed by workers of lower caste people. These roads are constructed by destroying the place of this lower caste people. Then they were made to migrate to slums which is away from the main city and will be considered as the place of anti-social activities. This people who constructed the infrastructure of the city were never given the recognition they deserved. This exploitation of people of lower strata is not something which happened before several decades. In today's world, in spite of scientific advancement, only people of particular caste or community were forced to work as manual scavengers. No people of so called higher caste cleans the sewage. Thousands of people die in manual scavenging which is ignored by the government, media and by the people whose waste is cleaned by them.

Mother who works throughout the day ignoring her hunger to feed her children, resembles the conditions of the farmers of contemporary age. They work hard to cultivate food but they cannot have that. In Mother, these people are working hard under sun. But they couldn't even get proper food. She was working in a road construction without sandal to her sole. They work hard but the wage they were receiving istoo low for them to acquire even basic needs. Even during her time of pregnancy she climbed a sky scraper to earn a small amount of wages.

She spends her wages for buying things too cook food. She always inspires her children to become like Ambedkar so that they could live a better life and also help others. She feeds her children and ate only a little food so that that they could have something in morning. Though she is poor she wants her children to become like Ambedkar and to fight 
against the social injustice which they were experiencing. " Study, become an Ambedkar/ and let the baskets fall from my hands" (Mother 100). This is the dream of every Dalits till this age to change their social condition and to come forward in society. Ambedkar who fought against the oppressors is their role model. Ambedkar was considered as a Dalit leader by the higher class people. But he is not a leader to be narrowed down to a particular caste or group. He is the leader of everyone who is suppressed by the dominating powers in the society. He is the one who inspired several people of so called lower caste to overcome their suppression and win over the oppression.

Mother also worked as a maid in some houses. She rejected the food provide to her by her owner because of her self-respect. They may be poor but they have dignity which they don't want to lose at any cost. In those houses where she worked as maid, she became the prey for the owner's lustful eyes. She was also disturbed by men in market whom she chased away with sandals. "chasing anyone who nudged you deliberately/ with your sandal in your hand..." (Mother 101). This was the condition of Dalit woman, when she go out of her house. Women of so called lower caste were considered as commodity so that anyone can exploit her. Dalit women are easy to be exploited as there are considered to have no one to rise voice for them against such activities. Saraswathi Govindarajan in "Caste, Women, and Violence" states, "Thus the low caste and Dalit women carry a double Cross-first because they are born in Shudra and Dalit family and the second because they are born as women. The caste and gender factors join hands to crush her inhumanly" (157). When a woman of high class is sexually assaulted it catches the attention of the media from national to local. Several feminist movements starts to protest and the Police will do their job immediately to arrest the culprit. All these events happen when the victim is form the higher place of the society. But when crimes same happens to a woman of so called lower caste, such case will not be considered as the important one. Also when Mother returns to home she also has to 
face her drunkard husband. Even if a woman is from so called higher caste or from the high social class she is still the victim of patriarchy. Out of all caste division and suppression women is always at the victim end and takes severe damage over her life.

Long march is the walk against the human rights violation over renaming the Marathwada University. Thousands of Dalit people were killed, injured and raped. Several thousand Dalit people participated and only a few managed to reach the destination in Aurangabad. In the middle they were attacked by police in several places. Mother was so courageous as she stood in the first row in the Long March. Even when she was attacked by the police she never fell back and went to jail with her head held high. "going to jail with head held high..." (Mother 102).She lost her only son to the bullet of the police shootout. But she was so proud that she lost her son for the sake of Bhim and also ready to sacrifice her sons if she had more. They were fighting hard to establish their identity which the higher caste deny to give them. Life of dalits always includes fights and struggle to get their basic rights, they are constantly in a battle with the oppressors, which also suits to women who are also in same condition. They sacrificed a lot to get few of their rights.K.C. Das, in his Indian Dalits explains about the ideals of Dalit movements as, "Notwithstanding differences in the nature of Dalit movements and the meaning of identity, there has been a common quest- the quest for equality, self-dignity and eradication of untouchability" (57). They were never identified as human by the higher caste people. In her death bed she gave her hard earned money to Diksha Bhumi. Though she was not educated she always fought for unity and Ambedkar's principles. She never bought any fancy dresses or ornaments for herself. The whole life of the "Mother" deals only with her struggle to feed her children, educate them and to fight for rights for her children. She never had any desires for herself and never lived for herself. She gave everything to her children and for the welfare of the society. 
The stratification of people based on caste is a manmade convention which separates fellow human beings from another. There is no segregation by birth. Everyone in this world is equal irrespective of any divisions such as class, caste, race, religion, country etc. Their rights are their basic amenity which no one can deny. Their struggle and revolution will continue till they achieve their identity and rights. 


\section{Works Cited}

Das, K.C. Indian Dalits. Global Vision Publishing House, New Delhi, 2004.

Govindarajan, Saraswathy. Caste, Women and Violence. Dalit and Women, The Gurukul Summer Institute, 1992, pp. 149-157.

Lanjewar, Jyoti. Mother. An Anthology of Dalit literature: poems, Gyan Publishing House, New Delhi, 1992, pp. 99-103

Omvedt, Gail. Dalit Visions. Edited by Neeladri Bhattacharya, Orient Longman Limited, New Delhi, 1995. 